\title{
Icnofósseis da Formação Pacujá (Cambriano, Bacia Jaibaras, CE-Brasil).
}

\author{
Bruno Belila Rusinelli, Fresia Ricardi-Branco
}

\begin{abstract}
Resumo
A presente pesquisa tem como principal objetivo estudar a assembleia icnofossilifera que ocorre nos arenitos próximos a Pacujá-CE. Tanto a unidade estratigráfica quanto a interpretação destes registros se mostram controversos na bibliografia, sendo inseridos na Formação Pacujá, Bacia Jaibaras ou na Formação Ipu, Grupo Serra Grande da Bacia do Parnaíba. Esses registros de icnofósseis são as únicas evidências para uma biota bentônica dessa região, sendo importnates para entendermos os hábitos de vida dos organismos e as condições paleoambientais envolvidas na sua preservação. Foram descritas 6 amostras e 21 moldes em resina que variam de escavações horizontais retas a sinuosas e estruturas e impressões circulares. As análises petrográficas caracterizam essas rochas como QuartzoArenitos e as realizadas em Microscopia Eletrónica de Varredura e Espectroscopia por Energia Dispersiva (MEV/EDS) permitiram constatar presença de minerais de Titânio, cimentação por óxidos de ferro e argila. Tambem foram realizadas análises em FRX para fim de observar possíveis bioassinaturas microbiais.
\end{abstract}

\section{Palavras-chave:}

Icnofósseis, Tafonomia, Eopaleozoico.

\section{Introdução}

A pesquisa tem como objetivo complementar os estudos acerca dos icnofósseis preservados em arenitos próximo a Pacujá-CE, são registros de uma fauna de idade eopaleozoica, que na bibliografia possuí diferentes interpretações que os colocam como icnofósseis Edicarianos da Formação Pacujá (Cambriano), Bacia de Jaibaras ${ }^{1}$ ou como registros icnofossilíferos do Grupo Ipu (Siluriano), Bacia do Parnaíba². São encontrados nesses arenitos médios a grossos escavações horizontais, impressões e estruturas circulares que trazem dúvidas quanto a sua preservação. Assim, é necessário um estudo de mais detalhe quanto a sua tafonomia e as condições paleoambientais da assembleia icnofossilífera.

\section{Resultados e Discussão}

Foram descritas 6 amostras e 21 moldes em resina realizados em campo de icnofósseis, onde ocorrem principalmente escavações retas e sinuosas horizontais a estratificação em epirrelevo positivo e negativo, variando com espessuras de entorno de 2 a $3 \mathrm{~cm}$, associados a estruturas circulares a ovais em epirrelvo positivo com região central deprimida, variam de 3 a $18 \mathrm{~cm}$ de diâmetro. Para fins de complementar as descrições foram realizadas lâminas petrográficas sem lamínula sob os icnofósseis coletados, dessa forma com a petrografia e análise de Microscopia Eletrônica de Varredura e Espectroscopia por Energia Dispersiva (MEV/EDS) se constatou que são Quartzo-Arenitos, onde ocorrem em menor proporção minerais como Feldspato, Rutilo, Muscovita e Zircão. Os grãos minerais são cimentados por óxidos de ferro e argilas. Também foram observadas feições de borda corroída em grãos de Quartzo. Acreditase a preservação destes icnofósseis esta associada a esteiras microbianas, desta forma foram realizadas análises em duas amostras, uma no topo e na outra na base, por Florescência de Raio-X ( $\mu$-FRX) no Laboratório de Luz Sincrotron, para constatar a presença de bioassinaturas. Foram produzidos mapas elementais dos elementos Silício, Ferro, Enxofre, Cálcio, Manganês, Titânio, Vanádio, Cloro e Potássio.

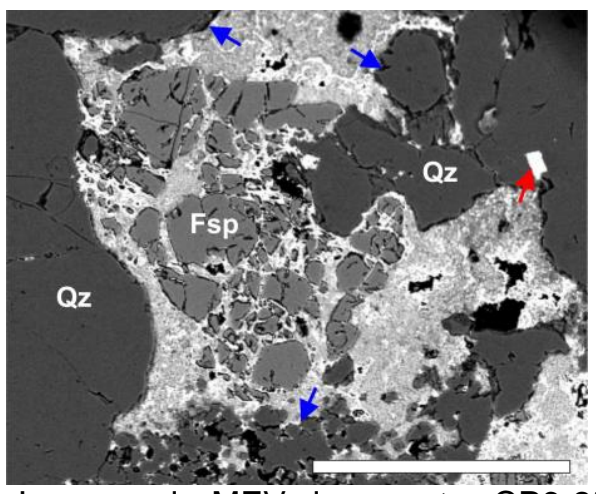

Figura 1. Imagem de MEV da amostra CP6-252, grãos intensamente fragmentados (Seta azul), ocorrem Quartzo, Feldspato Alcalino, Zircão (Seta vermelha)

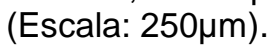

\section{Conclusões}

Os icnofósseis descritos, como as escavações, não são condizentes com a Biota de Ediacaria, já que estes são caracterizados no registro geológico como impressões. A presença de bordas corroídas em quartzos, de minerais pesados como zircão e rutilo contidos na matriz e a preservação destes registros em arenitos médios a grossos sugerem a atuação esteiras microbiais durante a fase inical da diagênese.

\section{Agradecimentos}

Agradeço a Fresia Ricardi-Branco pelo incentivo e orientação nesta pesquisa, também agradeço a Flávia Callefo (CNPEM) pela análise de m-FRX nas amostras, ao Marcelo Adorna Fernandes (Ufscar) pelo auxílio nas descrições dos icnofósseis. Por fim, agradeço ao $\mathrm{CNPq}$ pelo incentivo e pela oportunidade de bolsa.

\footnotetext{
${ }^{1}$ BARROSO, Francisco Rony Gomes. FAUNA DE EDIACARA NA BACIA DO JAIBARAS, NOROESTE DO CEARÁ: A PRIMEIRA OCORRÊNCIA NO NORDESTE DO BRASIL. 2012. 87 f. Dissertação (Mestrado) - Curso de Geociências, Centro de Tecnologia em Geociências, Universidade Federal de Pernambuco, Recife, 2012

2 VIANA, Maria Somália Sales et al. Ocorrências Icnofossiliferas do Grupo Serra Grande (Siluriano da Bacia do Parnaíba), Noroeste de Estado de Ceará. Revista de Geologia, Fortaleza-ce, v. 23, n. 1, p.49-89, nov. 2010.
} 